\title{
Article \\ Coupling Ecological Security Pattern Establishment and Construction Land Expansion Simulation for Urban Growth Boundary Delineation: Framework and Application
}

\author{
Dan Yi ${ }^{1,2} \mathbb{D}, X_{i} G_{0}{ }^{2}$, Yi Han ${ }^{2,3}$, Jie Guo ${ }^{1}$, Minghao Ou ${ }^{1}$ and Xiaomin Zhao ${ }^{2, *}$ \\ 1 College of Public Administration, Nanjing Agricultural University, Nanjing 210095, China; \\ 2020209021@njau.edu.cn (D.Y.); guojie@njau.edu.cn (J.G.); mhou@njau.edu.cn (M.O.) \\ 2 Key Laboratory of Poyang Lake Watershed Agricultural Resources and Ecology of Jiangxi Province, \\ Jiangxi Agricultural University, Nanchang 330045, China; guoxi@jxau.edu.cn (X.G.); \\ 202031051071@mail.bnu.edu.cn (Y.H.) \\ 3 State Key Laboratory of Earth Surface Processes and Resource Ecology, Faculty of Geographical Science, \\ Beijing Normal University, Beijing 100875, China \\ * Correspondence: zhaoxm889@126.com; Tel.: +86-13970024790
}

\section{check for}

updates

Citation: Yi, D.; Guo, X.; Han, Y.; Guo, J.; Ou, M.; Zhao, X. Coupling Ecological Security Pattern Establishment and Construction Land Expansion Simulation for Urban Growth Boundary Delineation: Framework and Application. Land 2022, 11, 359. https://doi.org/ 10.3390/land11030359

Academic Editor: Alexandru-Ionut Petrişor

Received: 10 February 2022 Accepted: 25 February 2022 Published: 1 March 2022

Publisher's Note: MDPI stays neutral with regard to jurisdictional claims in published maps and institutional affiliations.

Copyright: (C) 2022 by the authors. Licensee MDPI, Basel, Switzerland. This article is an open access article distributed under the terms and conditions of the Creative Commons Attribution (CC BY) license (https:// creativecommons.org/licenses/by/ $4.0 /)$.

\begin{abstract}
Reasonable delineation of the urban growth boundary (UGB) plays a vital role in guiding orderly urban space growth and ensuring urban environmental health. Existing methodologies for UGB delineation have failed to address the significance of ecological security. Therefore, this study presents a framework that couples ecological security pattern (ESP) establishment and construction land expansion (CLE) simulation to delineate the UGB. The proposed framework is applied to the Nanchang Metropolitan Area (NCMA) in southeastern China. First, we established the regional ESP of the NCMA in 2018 based on an improved minimum cumulative resistance model. The areas of low-, medium-, and high-level ESP were 1050.75, 736.42, and $720.59 \mathrm{~km}^{2}$, respectively. Second, we implemented a multi-scenario simulation of CLE in the NCMA in 2025 based on a cellular automata-Markov model. A natural development scenario was superior to urban growth and ecological protection scenarios for social, economic, and ecological development at the regional scale. Accordingly, we delineated the UGB of the NCMA in 2025 with a scale of $687.87 \mathrm{~km}^{2}$, based on dynamic adjustment using the results of ESP establishment and CLE simulation in the natural development scenario. The rationality and scientificity of the proposed framework were verified by comparing the scale and layout of the delineated UGB with the regional planning of Nanchang City. The framework incorporating dynamic adjustment with ESP establishment and multi-scenario CLE simulation provides a useful tool for the delineation of the UGB in similar urbanized cities. Its application is conducive to achieving a win-win outcome of regional ecological security and urban development.
\end{abstract}

Keywords: ecological source; multi-scenario simulation; urban growth boundary; improved minimum resistance model; CA-Markov model; Nanchang Metropolitan Area

\section{Introduction}

Intense urbanization is ongoing worldwide [1]. Today, the average construction land around the world is expanding twice as fast as its population [2]. It is estimated that global construction land is expected to increase by three times that present in 2000 by 2030 [3], which suggests that construction land expansion (CLE) is inevitable in the future. As construction land expands, a knowledge of the CLE style [4], differences [5,6], and determinants [7-9] are necessary to develop prudent land-use policies to enhance land-use efficiency, since CLE is often at the expense of farmland, forest, or grass, which ensures essential ecological security to society [10]. There has been considerable evidence that the CLE may have a series of resource, environmental, and socio-territorial repercussions [11-13]. 
On the one hand, CLE encroaches on farmland, threatening food security [14-16]. On the other hand, CLE converts natural lands into construction that leads to irreversible ecological damage, including the instability of ecosystem structure [17], the decrease of biological diversity [18], and the degradation of ecological functions [19]. All these have seriously threatened the human environment and restricted the realization of Sustainable Development Goal 2 "zero hunger" and 15 "life on land". To ameliorate these issues, many policy tools have been put forward and applied recently, including land-use planning [20-22], master planning [23-26], and urban growth boundaries (UGB) [27-29]. Among them, the UGB, an effective tool to guide orderly development and guarantee compactness of cities, has been widely used to control scale and ensure the healthy development of cities [30].

The history of the UGB can be traced back to the concept of greenbelt mentioned by Howard in the book "Garden Cities" in the late 19th century, which was well applied in the later Greater London planning [31]. At that time, the UGB was mainly emphasized as the boundary line between urban and rural. Staley believes that the purpose of the UGB is to guide the optimization of spatial patterns to restrain disorderly urban sprawl and further validates his view with the case of the UGB delineation in Portland [32]. Since then, the UGB has emerged as one of the most important approaches for optimizing the spatial pattern of cities around the world, with countries such as the United States [27,33], Switzerland [22], and Iran [34,35] all finding that the UGB is an effective tool to control the disorderly sprawl of cities. On this basis, subsequent studies have paid significant attention to the UGB in both theory and practice [36]. Furthermore, the UGB is being used by an increasing number of local governments to constrain urban development to a fixed area, which has been gradually recognized in various countries as a planning tool [37]. The methods of UGB delineation can be divided into three major categories [38], including the ecologically constrained method with the consideration of ecological control elements (e.g., ecological red lines and permanent basic farmland) from the ecological protection perspective [39-41], the expansion-driven method that starts from development demand based on the land-use change simulation model (e.g., CA-Markov, CLUE-S, SLEUTH, FLUS) [42-45], and the comprehensive method integrating the ecologically constrained and expansion-driven [46-48].

The connotation of the UGB has evolved from the "boundary line between urban and rural" [29] to "guiding line for optimizing spatial pattern" [40,41], which puts forward higher and more comprehensive requirements for the delineation of the UGB. UGB delineation by integrating the ecologically constrained and expansion-driven can not only take into account the ecological security and development demand but also enrich the research on the delineation method of the UGB [49]. The existing ecological constraints are mainly carried out with an ecological evaluation, which lacks a standardized theoretical basis and method as it involves a wide range of disciplines and many elements [50,51]. The concept of ecological security patterns (ESP) refers to the elements of landscapes, such as ecological source patches, which are critical to ecological security [52]. The ESP establishment can be regarded as the spatial identification of existing or potential key ecological elements, which can realize the protection of ecological security [53]. Since there are mature research paradigms for ESP establishment, the external ecologically constrained can be achieved with it to maintain the integrity of ecosystem structure, function, and process. In addition, the prediction of internal development demand is also essential in UGB delineation. cellular automata (CA)-Markov integrates the spatial simulation function of the CA model and absorbs the quantitative prediction advantage of the Markov model, which is widely used in the CLE simulation $[54,55]$. Therefore, giving the ESP establishment and CLE simulation enough emphasis in the delineation of the UGB will not only enhance its rationality and scientificity but also be key to achieving sustainable development goals.

This paper presents a UGB delineation framework that couples ESP establishment and construction land expansion (CLE) simulation. The proposed framework combines the rigid protection requirements of ecological security and the elastic development needs of construction land. The practicality and rationality of the framework were evaluated 
in the Nanchang Metropolitan Area (NCMA) of Nanchang City, Jiangxi Province, China. The aim of the study was to design a scientific method of UGB delineation and provide an applicable tool for orderly development in rapidly urbanized cities. This study should be useful for achieving a win-win outcome between regional urban development and ecological protection and guarantee the effective sustainable urban development of cities.

\section{Conceptual Framework}

In this study, we develop an operational and transdisciplinary framework that couples ESP establishment and CLE simulation to delineate the UGB, which would be characterized by both rigidity and elasticity with the consideration of ecological bottom line and development needs comprehensively. The framework comprises three steps (Figure 1): (1) establishing the regional ESP based on the improved minimum cumulative resistance (iMCR) model; (2) simulating multi-scenario CLE based on the CA-Markov model, and (3) delineating the UGB by coupling ESP establishment with CLE simulation.

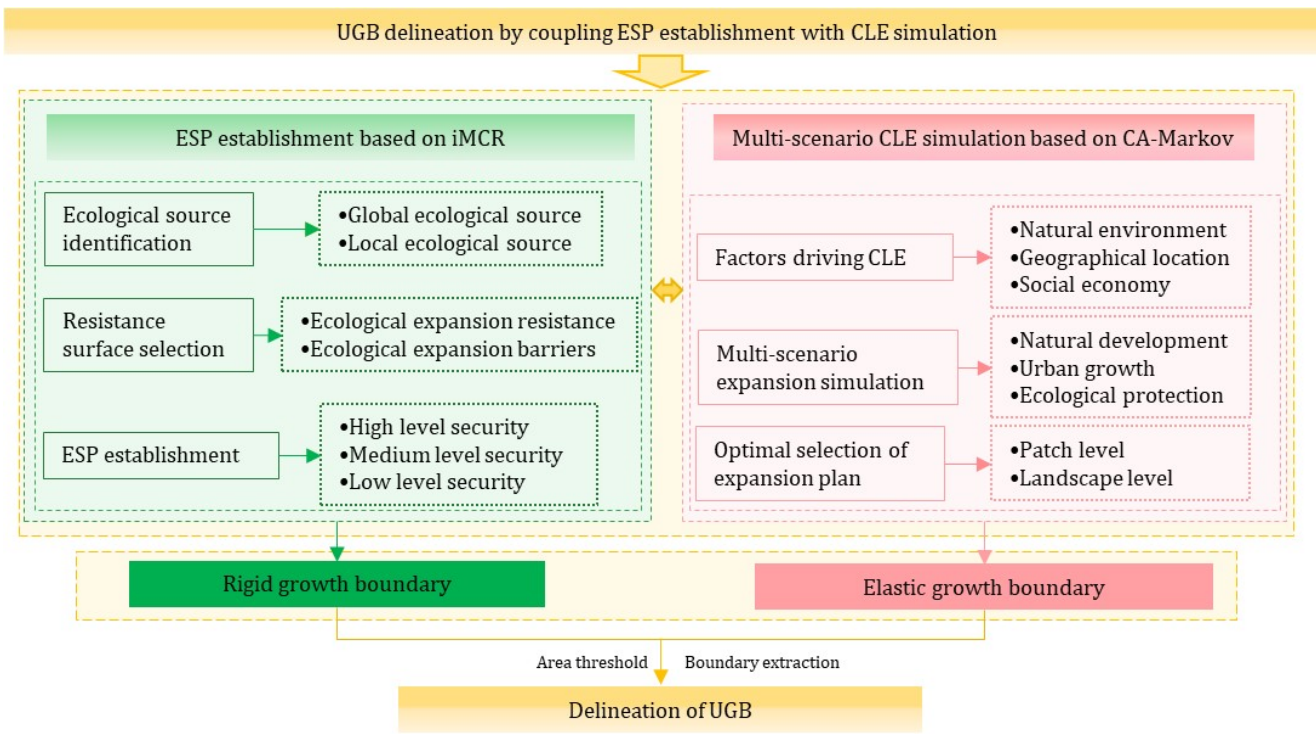

Figure 1. The research framework for delineation of the urban growth boundary (UGB) by coupling ecological security pattern (ESP) establishment with construction land expansion (CLE) simulation. iMCR: improved minimum cumulative resistance model; CA-Markov: cellular automataMarkov model.

\subsection{Ecological Security Pattern (ESP) Establishment}

Establishing the regional ESP helps to regulate the ecological processes and guarantee the ecological functions of the ecosystem; it also facilitates the efficient and reasonable allocation of regional natural resources and green infrastructure, ultimately achieving the goal of ecological security [56,57]. A general paradigm of this paper is "ecological source identification-resistance surface selection-ESP establishment" [58].

\subsubsection{Ecological Source Identification}

Available methods for identifying ecological sources generally gather data on the natural reserves, forests, and farmland through direct picking, or collect data on the land with high ecological value and strong ecological function by selecting multi-level indexes to construct a comprehensive evaluation system [59]. The direct-picking method ignores the internal differences between the same land-use types, while the index evaluation method ignores the macro-control of ecological security. Considering the pros and cons of different methods, global and local ecological sources are identified from both macroscopic and microscopic perspectives in the proposed research framework.

Specifically, the identification of global ecological sources targets patches that play a dominant role in the overall ESP of the region at the macro level. The identification of 
local ecological sources targets patches that have high ecological importance, high landscape connectivity, and high ecological demand at the micro-level, which is an important complement to the global ecological source. Considering that the identified ecological sources need to reach a certain area, the local ecological sources that are superimposed on the global ecological sources are determined to be global ecological sources. In addition, the ecological sources smaller than $2 \mathrm{~km}^{2}$ are eliminated, and the remaining patches are taken as the final local ecological sources [50].

\subsubsection{Resistance Surface Selection}

The resistance surface is a concrete representation of landscape resistance to the ecological source during the course of expansion. Due to the differing characteristics of the resistance surface, the resistance to the ecological source varies throughout the expansion process [60]. The resistance coefficient indicates the difficulty of passing through other landscapes during ecological source expansion [40]. In the proposed framework, the resistance surface is selected with regard to ecological expansion resistance and obstacles. The ecological expansion resistance mainly includes the influence of natural factors, location conditions, and ecological protection during ecological source expansion, for which the resistance coefficient can be obtained by setting the resistance interval and using the analytic hierarchy process [61]. Ecological expansion obstacles are insurmountable rigid constraints on ecological source expansion, with an infinite resistance coefficient [39].

\subsubsection{ESP Establishment}

According to the selected resistance surface, ESP can be established through spatial analysis. In the proposed framework, ESP is established based on the selected resistance surface and divided into high, medium, and low ecological security levels [62]. The identified ESP levels can serve as a rigid growth boundary of the region (Figure 1).

\subsection{Construction Land Expansion (CLE) Simulation}

The analysis of factors driving land-use change reveals the mechanisms underpinning CLE, while the simulation of land-use change obtains the optimal allocation of land use under different scenarios in the future. Furthermore, landscape pattern indexes indicate the complexity of the landscape spatial structure and provide useful information for decision-makers.

\subsubsection{Driving Factor Selection}

Reasonable selection of the factors driving CLE is crucial for multi-scenario simulation. CLE is not restricted by a single condition, but it is controlled by a combination of multiple factors [63]. In the proposed framework, several factors associated with the natural environment, geographical location, and socioeconomic status are selected to identify the factors driving CLE.

\subsubsection{Multi-Scenario Simulation}

Future changes in land-use patterns are full of complexity and uncertainty. Land-use changes under different development situations in the future can be simulated by a multiscenario setting. Based on the analysis of ESP establishment and CLE simulation, three scenarios are tested in the proposed framework (Table 1): natural development, urban growth, and ecological protection. Different scenarios have variable constraints. 
Table 1. Details of three different scenarios tested in the framework for delineation of the urban growth boundary (UGB).

\begin{tabular}{ll}
\hline Scenarios & Description \\
\hline $\begin{array}{l}\text { Natural } \\
\text { development }\end{array}$ & $\begin{array}{l}\text { A natural extrapolation of the historical land use quantitative structure } \\
\text { change trend, with all types of land maintaining their original growth } \\
\text { or decline trends }\end{array}$ \\
\hline Urban growth & $\begin{array}{l}\text { Providing that new construction land can occupy a small amount of } \\
\text { forest land and unused land, but not water; adopt the ordered weighted } \\
\text { averaging (OWA) method to highlight the influence and role of relevant } \\
\text { planning and regional development policies on the expansion of } \\
\text { construction land }\end{array}$ \\
\hline Ecological protection & $\begin{array}{l}\text { Set permanent basic farmland areas in the region as well as nature } \\
\text { reserves as restrictive factors; prohibit the conversion of water for other } \\
\text { land-use types }\end{array}$ \\
\hline
\end{tabular}

\subsubsection{Optimal Scenario Selection}

Landscape pattern indexes indicate landscape composition and spatial characteristics [64]. The different values of landscape pattern indexes based on multi-scenario simulation are useful for decision-makers to choose future development situations [65]. In the proposed framework, landscape pattern indexes are selected at the patch and landscape levels to analyze the ecological effect of different simulation scenarios. Then, the optimal scenario is determined and the simulated construction land is taken as the elastic growth boundary (Figure 1).

\subsection{Urban Growth Boundary (UGB) Delineation}

Coupling is a physical concept that initially referred to the phenomenon of close fit and the interaction between two or more circuit elements or networks, or the transfer of energy between each other [66]. In the present study, "coupling" is defined as the combination of two processes involving ESP establishment and CLE simulation to delineate the UGB based on the perspective of ecological security and development demand. Since the UGB is the maximum boundary for CLE during a certain period, it represents the continuous contour of concentrated and contiguous construction land, and it should contain as much contiguous and large construction land as possible. Therefore, the procedure of UGB delineation that couples ESP establishment and CLE simulation can be summarized as follows.

First, the established ESP is superimposed with the CLE simulated in the optimal scenario, and the superimposed construction land patches are adjusted dynamically. When the superimposed patches conflict with the low-level ESP, the priority of the coordination principle is to protect the ESP and transfer the construction land patches out; when the superimposed patches conflict with the medium-level ESP, the priority of the coordination principle is to protect the urban growth needs and keep the construction land patches. Then, on the basis of dynamic coordination, the adjusted results are scaled with area threshold, hole filling, and boundary extraction to obtain the final UGB [38].

\section{Case Study}

\subsection{Study Area}

The Nanchang Metropolitan Area (NCMA) is located in the north-central area of Nanchang City, Jiangxi Province (Figure 2), bordering Poyang Lake-the largest freshwater lake in China. The NCMA consists of six administrative districts and two counties of Nanchang City. The land area of the NCMA is $2507.76 \mathrm{~km}^{2}$, accounting for $34.58 \%$ of the total area of Nanchang City. There are many nature reserves in the NCMA with an excellent ecological environment, which is suitable for wildlife. The topography of the NCMA is undulating (high in the northwest and low in the southeast), with a low, flat terrain and a dense water network. Due to the subtropical monsoon climate, the NCMA is prone to flood disasters during summers with concentrated rainfall. 


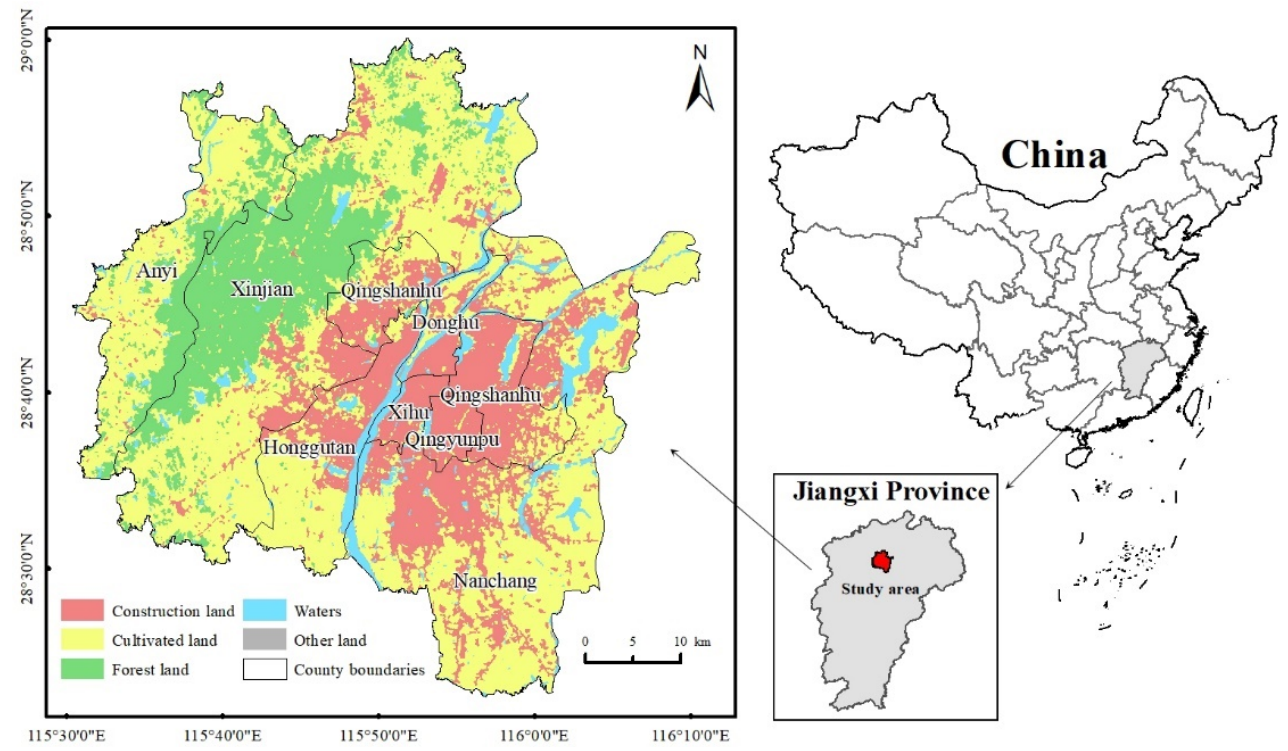

Figure 2. Location of the study area and land use of the Nanchang Metropolitan Area in 2018.

In the wake of rapid economic development, the construction land area in the NCMA has increased considerably from $164.62 \mathrm{~km}^{2}$ in 2000 to $614.19 \mathrm{~km}^{2}$ in 2018 , with a mean annual expansion rate of $24.98 \mathrm{~km}^{2}$ /year (http:/ / tjj.nc.gov.cn/ (accessed on 1 February 2022)). The rapid expansion of construction land is accompanied by drastic changes in the structure and function of the regional ecosystem, posing a threat to its sustainable development. Therefore, delineating the UGB reasonably and controlling the expansion of construction land effectively to maintain the stability of ecosystem structure and function are the main missions to be implemented during the course of urbanization in the NCMA.

\subsection{Data Acquisition and Processing}

The data used in this study included remote sensing image data, basic geographic information data, and other related data (see more in Supplementary Materials of Table S1). The collected data were processed via land-use classification based on remote sensing images and the unification of raster and vector data.

\subsection{Methods}

3.3.1. Ecological Security Pattern (ESP) Establishment Based on the Improved Minimum Cumulative Resistance (iMCR) Model

\section{- $\quad$ The $i M C R$ model}

There are two problems in the establishment of ESP based on the traditional minimum cumulative resistance (MCR) model. One is that ecological sources differ greatly in their expansion capacity across locations. The other is that the rigid obstacles to the expansion of ecological sources are not distinguished. To address these problems, Ye et al. (2015) modified the MCR model by introducing the relative resistance coefficient for different levels of ecological sources [39]. The obtained $i M C R$ model is expressed by Equation (1):

$$
i M C R=f_{\min }\left(\sum_{j=n}^{i=m} D_{i j} \times R_{i} \times K_{j}\right)
$$

where $i M C R$ represents the $i M C R$ value, $f$ is an unknown negative function, $\min$ is the minimum value of a source for different landscapes, $D_{i j}$ denotes the distance from source $j$ to land unit $i, R_{i}$ is the resistance coefficient, and $K_{j}$ denotes the relative resistance coefficient for different levels of ecological sources.

- Global and local ecological source identification 
At the macro level, data on global ecological sources were gathered by direct picking according to the resource endowment status and ecological protection needs of the study area, whose expansion coefficient was set to 1 [39]. Some areas of forest land and waters in the NCMA were taken as global ecological sources based on the information from the general land-use planning of Nanchang (2006-2020, hereinafter referred to as the general plan) and the master urban planning of Nanchang (2016-2035, hereinafter referred to as the master plan), combined with field investigation.

At the micro level, local ecological sources were analyzed to identify the areas with high ecological importance, high landscape connectivity, and high ecological demand, whose expansion coefficient was set to 0.8 [39]. A local ecological source evaluation system was constructed based on the perspective of ecosystem function and ecological demand (see more in Supplementary Materials of Figure S1). The ecosystem function in terms of ecological importance and landscape connectivity was calculated using Equation (2) [51]:

$$
L E S I=E F_{i}+E D_{i}=\frac{(E I+L C)_{i}-(E I+L C)_{\min }}{(E I+L C)_{\max }-(E I+L C)_{\min }}+\frac{E D_{i}-E D_{\text {min }}}{E D_{\max }-E D_{\min }}
$$

where LESI represents the local ecological source importance index of grid $i, E F_{i}$ is the normalized ecosystem function value of grid $i, E D_{i}$ is the normalized ecological demand value of grid $i, E I_{i}$ is the normalized ecological importance index value of grid $i, L C_{i}$ is the normalized landscape connectivity index value of grid $i,(E I+L C)_{i}$ is the normalized sum of ecosystem function index value of grid $i,(E I+L C)_{\max }$ and $(E I+L C)_{\min }$ represent the maximum and minimum values of ecosystem function index, respectively, and $E D_{\max }$ and $E D_{\text {min }}$ represent the maximum and minimum values of ecological demand in all grids, respectively.

With regard to ecological importance, habitat quality was obtained through the Habitat Quality module in InVEST v3.7 [67]. Soil conservation characterized by soil erosion sensitivity was extracted from the soil erosion data of Jiangxi Province provided by the Provincial Department of Natural Resources based on the Revised Universal Soil Loss Equation [68]. Water security was described by considering both water resource importance and flood security importance [69]. As for landscape connectivity, the integral index of connectivity of patches in different areas was obtained using ArcGIS v10.2 (ESRI Inc., Redlands, CA, USA) and Conefor Sensinode v2.6 [70]. Furthermore, ecological demand intensity was portrayed with DMSP/OLS nighttime lighting satellite data to indicate the intensity of human activity and population concentration [71].

- Resistance surface evaluation

The $i M C R$ model considers the obstacles to the expansion of ecological sources, in addition to the resistance received [39]. In the present study, expansion resistance factors were selected from natural factors, location conditions, and ecological protection [57,72,73], and their resistance coefficients were obtained using the analytic hierarchy process [61]. Moreover, expansion resistance obstacles were obtained within the scope of projects under construction or proposed in 2018-2019, and they were determined in the permitted construction areas and conditional construction areas by combining the general plan of Nanchang (2006-2020) and field investigation data. The resistance coefficient of expansion resistance obstacles was set to 9999 in practice (Table 2). 
Table 2. Evaluation indexes of ecological resistance in the NCMA.

\begin{tabular}{|c|c|c|c|c|c|c|c|c|}
\hline \multirow{2}{*}{ 1st Index } & & \multirow{2}{*}{ 2nd Index } & \multicolumn{5}{|c|}{ Resistance-Level Interval } & \multirow{2}{*}{$\begin{array}{l}\text { Resistance } \\
\text { Coefficient }\end{array}$} \\
\hline & & & 1 & 3 & 5 & 7 & 9 & \\
\hline \multirow{9}{*}{$\begin{array}{l}\text { Expansion } \\
\text { resistance }\end{array}$} & \multirow{4}{*}{$\begin{array}{l}\text { Natural } \\
\text { factors }\end{array}$} & $\begin{array}{l}\text { Digital elevation } \\
\text { model }\end{array}$ & {$[520,827)$} & {$[350,520)$} & {$[200,350)$} & {$[90,200)$} & {$[14,90)$} & 0.067 \\
\hline & & Slope & {$[30,82)$} & {$[18,30)$} & {$[8,18)$} & {$[2,8)$} & {$[0,2)$} & 0.065 \\
\hline & & $\begin{array}{l}\text { Normalized } \\
\text { difference } \\
\text { vegetative Index }\end{array}$ & {$[0.4,1)$} & {$[0.3,0.4)$} & {$[0.2,0.3)$} & {$[0.1,0.2)$} & {$[-0.1,0.1)$} & 0.077 \\
\hline & & Land-use type & $\begin{array}{l}\text { Forest land } \\
\text { and waters }\end{array}$ & $\begin{array}{l}\text { Cultivated } \\
\text { land }\end{array}$ & Other land & / & $\begin{array}{l}\text { Construction } \\
\text { land }\end{array}$ & 0.096 \\
\hline & \multirow{2}{*}{$\begin{array}{l}\text { Location } \\
\text { conditions }\end{array}$} & $\begin{array}{l}\text { Distance from } \\
\text { major roads }\end{array}$ & {$[12,25)$} & {$[8,12)$} & {$[4,8)$} & {$[2,4)$} & {$[0,2)$} & 0.113 \\
\hline & & $\begin{array}{l}\text { Distance from } \\
\text { built-up areas }\end{array}$ & {$[4.5,8)$} & {$[3.2,4.5)$} & {$[2,3.2)$} & {$[0.8,2)$} & {$[0,0.8)$} & 0.133 \\
\hline & \multirow{3}{*}{$\begin{array}{l}\text { Ecological } \\
\text { protection }\end{array}$} & $\begin{array}{l}\text { Distance from } \\
\text { water bodies }\end{array}$ & {$[0,4)$} & {$[4,8.5)$} & {$[8.5,13)$} & {$[13,18)$} & {$[18,22)$} & 0.169 \\
\hline & & $\begin{array}{l}\text { Ecological red } \\
\text { line zone }\end{array}$ & $\begin{array}{l}\text { Ecological red } \\
\text { line zone }\end{array}$ & / & / & / & $\begin{array}{l}\text { Non- } \\
\text { ecological red } \\
\text { line zone }\end{array}$ & 0.144 \\
\hline & & $\begin{array}{l}\text { Permanent basic } \\
\text { farmland area }\end{array}$ & $\begin{array}{l}\text { Permanent } \\
\text { basic farmland } \\
\text { area }\end{array}$ & / & / & / & $\begin{array}{l}\text { Non- } \\
\text { permanent } \\
\text { basic } \\
\text { farmland } \\
\text { area }\end{array}$ & 0.135 \\
\hline \multicolumn{2}{|c|}{ Expansion obstacle } & $\begin{array}{l}\text { Projects under } \\
\text { construction or } \\
\text { proposed }\end{array}$ & \multicolumn{5}{|l|}{ / } & 9999 \\
\hline
\end{tabular}

3.3.2. Multi-Scenario Construction Land Expansion (CLE) Simulation Based on the CA-Markov Model

- The CA-Markov model

The CA-Markov model consists of the Markov chain, multi-criteria evaluation, and cellular automata. It combines the advantages of both Markov prediction and cellular automata effectively to create a land-use transfer suitability atlas based on multi-criteria evaluation for selected factors driving land expansion [55]. The CA-Markov model was applied to simulate construction land expansion (CLE) in this study, and the prediction process is expressed as Equation (3) [54]:

$$
C\left(t_{j+1}\right)=F\left[C\left(t_{j}\right), N\right]
$$

where $C\left(t_{j}\right)$ and $C\left(t_{j+1}\right)$ represent the state of a cell at the time $t_{j}$ and $t_{j+1}$, respectively (the cell state in this study is the land-use type attribute corresponding to each grid unit); $F$ is the transformation rule, which is the embodiment of the logical relationship in the simulation process and determines the results of spatial change; $N$ is the neighborhood of the cell. The CA-Markov model was implemented in IDRISI Selva v17.0 (https: / clarklabs.org / (accessed on 1 February 2022)), while the basic land-use data of the NCMA in the years 2000, 2010, and 2018 were pre-processed in Envi v5.5 (Harris Geospatial Solutions Inc., Broomfield, CO, USA). Then, the kappa coefficient was applied to evaluate the accuracy of CA-Markov by comparing the simulation results with historical data in 2018 [74-76].

- Selection of factors driving construction land expansion

Elevation, slope, distance from the national highway, distance from the provincial highway, distance from the railway, and public infrastructure density were selected to analyze the factors driving construction land expansion. The spatial distribution of each selected factor in the NCMA is shown in Figure S2 (see more in Supplementary Materials).

- Optimal scenario selection based on landscape pattern indexes

All landscape pattern indexes can be divided into three categories, patch level, class level, and landscape level. In this study, three patch-level indexes-patch density (PD), 
area-weighted mean shape index (AWMSI), and mean patch fractional dimension (MPFD) were selected to indicate the fragmentation, shape, and regularity of land-use structures in the multi-scenario simulation of the number, perimeter, and area of patches, respectively. At the landscape level, the contagion index (CONTAG), interspersion and juxtaposition index (IJI), landscape division index (DIVISION), and Shannon's diversity index (SHDI) were selected to indicate the stability among landscapes in the multi-scenario simulation. The patch-level and landscape-level indexes were calculated using Fragstats v4.2 (https: //www.umass.edu/landeco/research/fragstats / (accessed on 1 February 2022)), and the results were analyzed to determine the optimal scenario. Table S2 summarizes the meanings of different landscape pattern indexes (see more in Supplementary Materials).

\subsubsection{UGB Delineation Coupling ESP Establishment and CLE Simulation}

The delineation of the UGB needs to be "rigid and elastic". First, iMCR-based ESP establishment provides information for a rigid boundary of urban development to protect ecological security. Second, multi-scenario CLE simulation defines the scope for an elastic boundary of urban development to meet the social-economic needs [20]. Here, these two processes (ESP establishment and CLE simulation) were combined to delineate the UGB, as expressed in Equation (4):

$$
\mathrm{UGB}=\mathrm{UGB}_{M C R^{\prime}} \cap \mathrm{UGB}_{C A-M a r k o v}
$$

where $\mathrm{UGB}_{M C R^{\prime}}$ is the boundary delineated based on the ESP established using the $i M C R$ model and $\mathrm{UGB}_{C A-M a r k o v}$ is the boundary obtained based on the CLE simulated using the CA-Markov model.

\subsection{Results}

\subsubsection{The Ecological Security Pattern (ESP) State in the NCMA}

- Spatial distribution of ecological sources

Both global and local ecological sources were identified in the NCMA in 2018 (Figure 3a). After removing patches less than $2 \mathrm{~km}^{2}$, the global ecological source area amounted to $526.44 \mathrm{~km}^{2}$, that is, $74.84 \%$ of the total ecological source area. Most patches of global ecological sources were forest land distributed in mountainous and hilly areas in the northwestern part of the study area, in addition to dozens of lakes and rivers. The identified local ecological source area was $176.96 \mathrm{~km}^{2}$, accounting for $25.16 \%$ of the total ecological source area. The patches of local ecological sources were mainly scattered in agricultural planting areas across the north-central, southeastern, and southwestern parts of the study area.
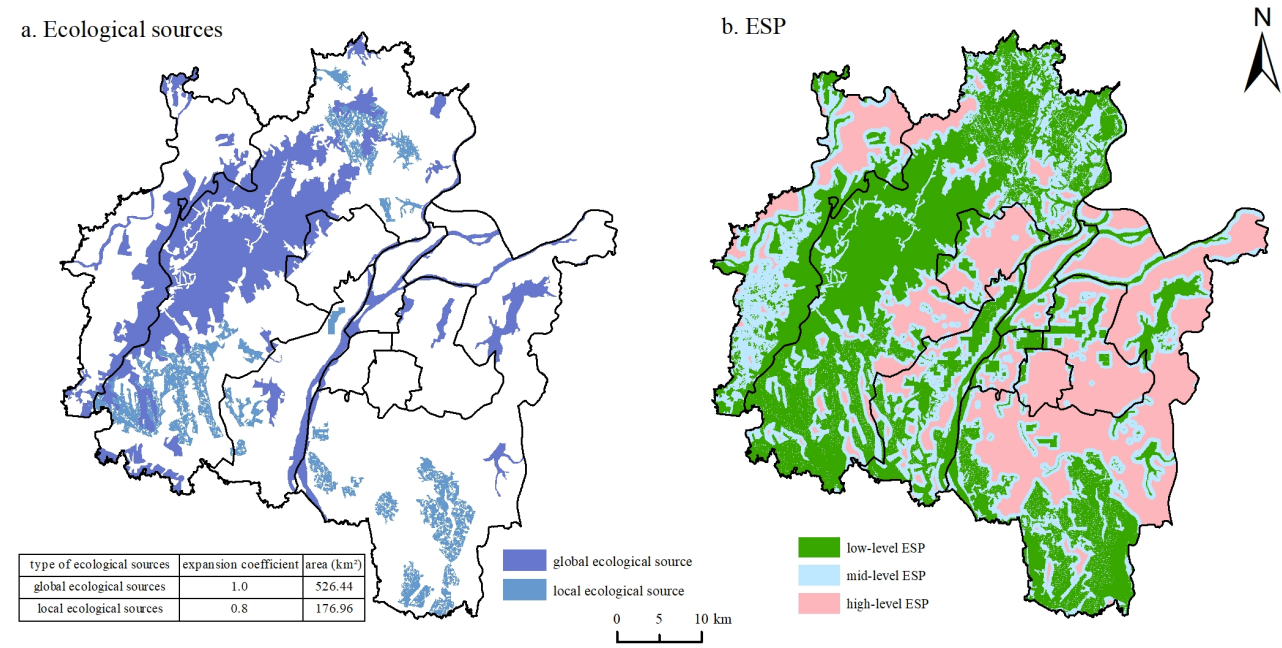

Figure 3. Spatial distribution of the ecological sources identified and the ecological security pattern (ESP) established in the study area in 2018. 
- Spatial distribution of ecological security pattern

The ESP of the NCMA was established based on iMCR (Figure 3b). Among the three different levels, low-level ESP was most prevalent (1050.75 km²), accounting for $41.90 \%$ of the total study area. Low-level ESP was mainly distributed in mountainous and hilly areas in the northwestern part and the contiguous farmland areas in the southern part of the study area, forming a core area of an insurmountable bottom line for regional ecological security. The area of mid-level ESP in the NCMA amounted to $736.42 \mathrm{~km}^{2}$, that is, $29.37 \%$ of the total study area. Specifically, mid-level ESP formed a "buffer" zone around low-level ESP, having strong ecosystem services and an anti-interference ability to the external world. The area of high-level ESP $\left(720.59 \mathrm{~km}^{2}\right)$ was slightly smaller than that of mid-level ESP, accounting for $28.73 \%$ of the total study area. High-level ESP was mainly distributed in the central and southern parts of the study area, where the material and energy exchanged between the human social system and natural ecological system.

\subsubsection{Construction Land Expansion (CLE) Simulation in Multi-Scenarios}

\section{- CLE simulated based on CA-Markov}

The multi-scenario simulation results of CLE in the NCMA in 2025 were obtained using different parameter settings (Figure 4). In all scenarios, construction land continued to expand outward during the evolution of land-use structure (Table 3). In the urban growth scenario, the expansion rate was the fastest, and the expanded construction land area was predicted to reach $905.87 \mathrm{~km}^{2}$. In contrast, cultivated land showed a downward trend in all the scenarios, with the largest decrease found in the urban growth scenario. Forest land also showed a downward trend in both the natural development and urban growth scenarios; however, in the ecological protection scenario, forest land area tended to increase, instead of decrease. The water area had a certain increase in each scenario, with the fastest rate found in the ecological protection scenario. The other land area showed an upward trend in the three scenarios, and there was little difference in the area change among the different scenarios.
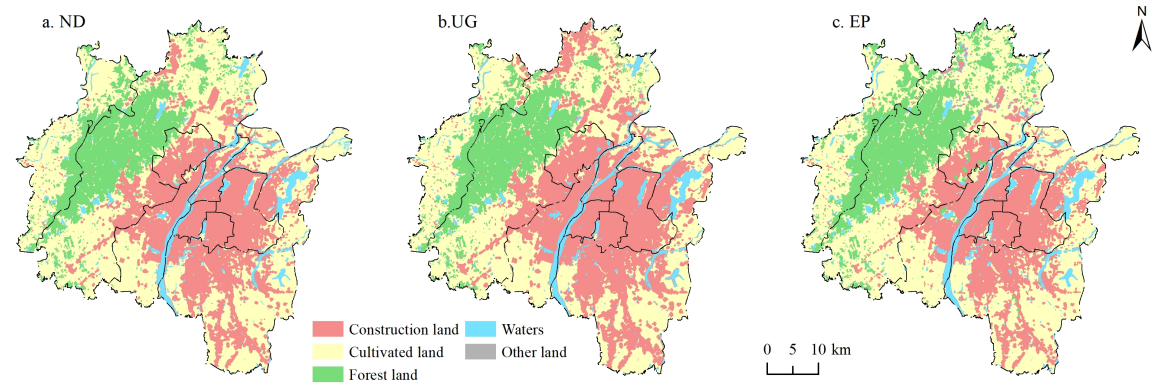

Figure 4. Simulation results of land use in the study area in 2025 under multiple scenarios. ND: natural development; UG: urban growth; EP: ecological protection.

Table 3. Multi-scenario simulation results of land-use change in the study area $\left(2018-2025 ; \mathrm{km}^{2}\right)$.

\begin{tabular}{|c|c|c|c|c|c|c|c|}
\hline \multirow{3}{*}{$\begin{array}{l}\text { Land-Use Type } \\
\text { Construction land }\end{array}$} & \multirow{3}{*}{$\begin{array}{l}2018 \\
614.23\end{array}$} & \multicolumn{6}{|l|}{2025} \\
\hline & & \multicolumn{2}{|c|}{ Natural Development } & \multicolumn{2}{|c|}{ Urban Growth } & \multicolumn{2}{|c|}{ Ecological Protection } \\
\hline & & 788.69 & $128.40 \%$ & 905.87 & $147.48 \%$ & 728.48 & $118.60 \%$ \\
\hline Cultivated land & 1301.48 & 1123.00 & $86.29 \%$ & 1032.03 & $79.30 \%$ & 1149.56 & $88.33 \%$ \\
\hline Forest land & 435.71 & 426.13 & $97.80 \%$ & 404.22 & $92.77 \%$ & 452.08 & $103.76 \%$ \\
\hline Waters & 145.32 & 152.00 & $104.60 \%$ & 148.00 & $101.84 \%$ & 161.03 & $110.81 \%$ \\
\hline Other land & 11.01 & 16.60 & $150.77 \%$ & 16.30 & $148.05 \%$ & 16.61 & $150.86 \%$ \\
\hline Sum & 2507.76 & 2507.76 & / & 2507.76 & / & 2507.76 & / \\
\hline
\end{tabular}

- Optimal scenario of CLE based on landscape pattern indexes 
The optimal scenario of CLE was selected by comparing the patch-level and landscapelevel indexes of different land-use types in the NCMA between 2018 and 2025 (Table 4). In the natural development scenario, the PD of each landscape type was predicted to increase in 2025 compared with 2018, while AWMSI of construction land and MPFD of cultivated land were predicted to decrease simultaneously. Among the landscape-level indexes, CONTAG, DIVISION, and SHDI were all predicted to increase, while LJI would decrease in 2025 compared with 2018. The results indicated that although the natural development scenario was somewhat favorable for the development of the urban social economy, it could affect the production function of cultivated land and destroy the landscape ecological functions, such as those of the woodland and water areas.

Table 4. Comparison of landscape pattern indexes in the study area between 2018 and 2025.

\begin{tabular}{|c|c|c|c|c|c|c|c|c|c|}
\hline \multicolumn{2}{|c|}{ Scenario } & \multirow{2}{*}{ Land-Use Type } & \multicolumn{3}{|c|}{ Patch Level } & \multicolumn{4}{|c|}{ Landscape Level } \\
\hline & & & PD & AWMSI & MPFD & CONTAG & LJI & DIVISION & SHDI \\
\hline \multirow{5}{*}{2018} & & Construction land & 0.179 & 11.72 & 1.062 & \multirow{5}{*}{58.067} & \multirow{5}{*}{59.067} & \multirow{5}{*}{0.854} & \multirow{5}{*}{1.178} \\
\hline & & Cultivated land & 0.408 & 17.593 & 1.053 & & & & \\
\hline & & Forest land & 0.319 & 6.28 & 1.05 & & & & \\
\hline & & Waters & 0.233 & 5.03 & 1.053 & & & & \\
\hline & & Other land & 0.073 & 2.1 & 1.059 & & & & \\
\hline \multirow{15}{*}{2025} & \multirow{5}{*}{ ND } & Construction land & 0.195 & 8.577 & 1.07 & \multirow{5}{*}{60.44} & \multirow{5}{*}{57.594} & \multirow{5}{*}{0.874} & \multirow{5}{*}{1.233} \\
\hline & & Cultivated land & 0.457 & 18.25 & 1.051 & & & & \\
\hline & & Forest land & 0.337 & 6.494 & 1.06 & & & & \\
\hline & & Waters & 0.355 & 5.289 & 1.054 & & & & \\
\hline & & Other land & 0.091 & 2.359 & 1.07 & & & & \\
\hline & \multirow{5}{*}{ UG } & Construction land & 0.564 & 7.84 & 1.056 & \multirow{5}{*}{60.394} & \multirow{5}{*}{57.867} & \multirow{5}{*}{0.875} & \multirow{5}{*}{1.233} \\
\hline & & Cultivated land & 0.345 & 19.759 & 1.056 & & & & \\
\hline & & Forest land & 0.335 & 6.73 & 1.059 & & & & \\
\hline & & Waters & 0.351 & 5.495 & 1.045 & & & & \\
\hline & & Other land & 0.134 & 2.157 & 1.086 & & & & \\
\hline & \multirow{5}{*}{$\mathrm{EP}$} & Construction land & 0.189 & 10.416 & 1.064 & \multirow{5}{*}{59.843} & \multirow{5}{*}{59.832} & \multirow{5}{*}{0.872} & \multirow{5}{*}{1.249} \\
\hline & & Cultivated land & 0.403 & 18.537 & 1.055 & & & & \\
\hline & & Forest land & 0.315 & 6.763 & 1.06 & & & & \\
\hline & & Waters & 0.366 & 4.986 & 1.054 & & & & \\
\hline & & Other land & 0.087 & 2.259 & 1.072 & & & & \\
\hline
\end{tabular}

ND: natural development; UG: urban growth; EP: ecological protection. PD: patch density; AWMSI: area-weighted mean shape index; MPFD: mean patch fractional dimension; CONTAG: the contagion index; IJI: interspersion and juxtaposition index; DIVISION: landscape division index; SHDI: Shannon's diversity index.

In the urban growth scenario, except for cultivated land, PDs of all other land-use types were predicted to increase in 2025 compared with 2018, and the increase was larger than that in the natural development scenario. The trends in the remaining six landscape pattern indexes were consistent with those in the natural development scenario. However, the range of changes in the patch-level indexes AWMSI and MPFD were larger than those in the natural development scenario, while the landscape-level indexes CONTAG, DIVISION, SHDI, and LJI had smaller changes than in the natural development scenario. According to these results, the urban growth scenario was beneficial to the development of the urban social economy, but the damage to the non-artificial landscape was greater than that in the natural development scenario.

In the ecological protection scenario, the PD of each landscape type showed a smaller range of change than in the other two scenarios. Both AWMSI and MPFD showed similar but smaller changes than in the natural development and urban growth scenarios, while CONTAG, LJI, DIVISION, and SHDI were predicted to increase in 2025 compared with 2018. The results showed that the landscape characteristics were beneficial to the maintenance of ecological service functions in the study area, while they were more vulnerable to the 
external environment. Overall, the natural development scenario was superior for social, economic, and ecological development at the regional scale.

\subsubsection{UGB of the NCMA in 2025 Based on the Optimal Scenario}

The established ESP was superimposed with the simulated construction land in the natural development scenario, and the scale of construction land in 2025 was predicted to be $788.69 \mathrm{~km}^{2}$. Combined with the actual situation, a dynamic coordination analysis of the superposition results was conducted. The patch area at the low level of ESP was $72.67 \mathrm{~km}^{2}$, and the principle of coordination ensures the level of regional ecological security by removing such patches from the intersection of construction land. The patch area at the mid-level ESP was $163.45 \mathrm{~km}^{2}$, and the coordination principle meets the needs of regional urban development by keeping such patches within the scope of the intersected construction land. The scale of construction land that can be developed in the NCMA in 2025 was preliminarily determined to be $716.02 \mathrm{~km}^{2}$ (Figure 5a).

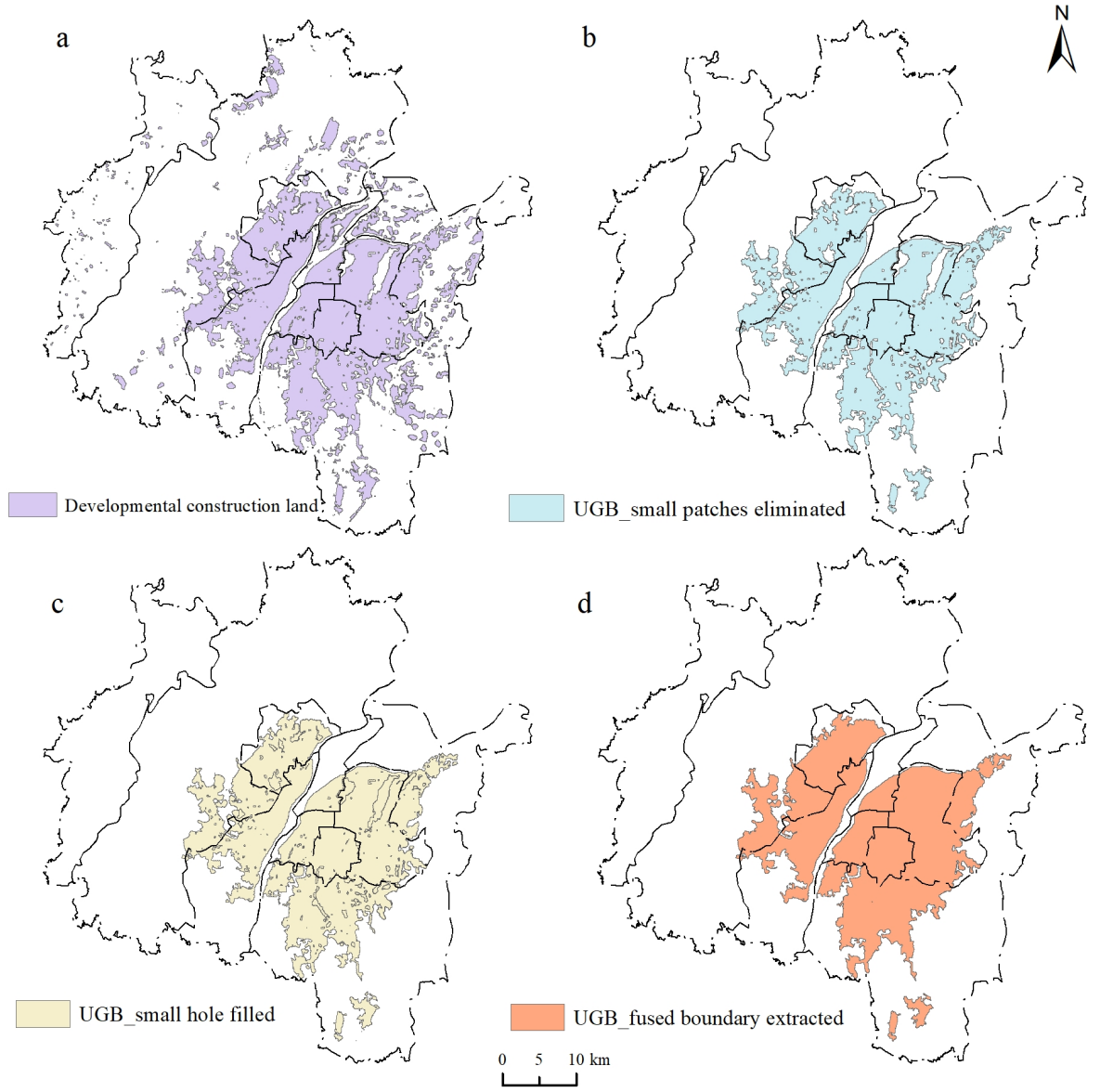

Figure 5. Schematic diagrams showing the extraction process of the revised urban growth boundary (UGB) in the study area in 2025 based on the natural development scenario ((a) developmental construction land; (b) small patches eliminated; (c) small holes filled; (d) fused boundary extracted).

According to the definition of the UGB (see Section 2.3), the scale of developmental construction land in 2025 (Figure 5a) was modified. After setting the area threshold, small patches were eliminated (Figure 5b), and small holes in the contiguous large area layer were filled (Figure 5c). Then, the boundary of the fused large area layer was extracted (Figure 5d). Finally, a UGB combining rigidity and elasticity was obtained at the scale of $687.87 \mathrm{~km}^{2}$. 


\section{Discussion}

\subsection{Quantitative Comparison of UGBs with and without ESP}

One of the major goals of UGB delineation is to protect regional ecological security and prevent encroachment on important ecological resources. These goals can be achieved by dynamic adjustment of the UGB with ESP $[38,41]$. Here, we compared UGB I, which was dynamically adjusted for ESP using UGB II, which was not dynamically adjusted for ESP, to evaluate the results of UGB delineation from an ecological protection perspective. The results showed that there were $8.34 \mathrm{~km}^{2}$ of construction land patches with low-level ESP using UGB I (Figure 6), accounting for $\sim 1.16 \%$ of the total developable construction land area in the NCMA in 2025. The construction land patches were scattered around the Ganjiang River with high ecological value in the central city. Additionally, there were $132.82 \mathrm{~km}^{2}$ of construction land patches with mid-level ESP using UGB I, accounting for $18.55 \%$ of the total developable construction land area in 2025 . The patches almost averted the low-level ESP area with high ecological value in the study area.

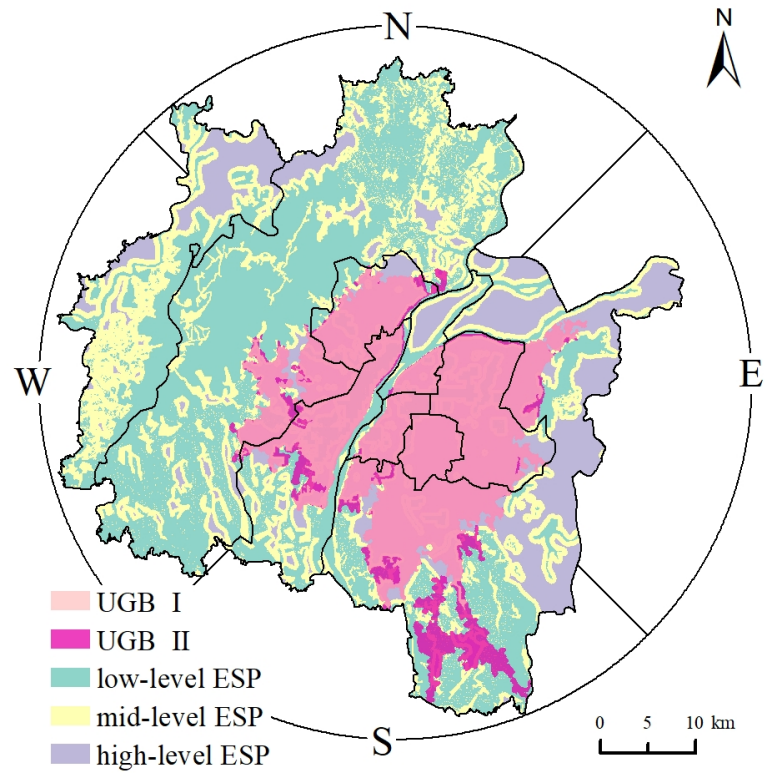

Figure 6. Comparison of the delineation results of urban growth boundary (UGB) without and with dynamic adjustment. ESP: ecological security pattern.

Using UGB II, there were $92.71 \mathrm{~km}^{2}$ of construction land patches with low-level ESP, accounting for $\sim 12.95 \%$ of the total construction land area in 2025 . The construction land patches were distributed around the waters of Qingshan Lake, Aixi Lake, and Xiang Lake, which have high ecological value in the central city. Some patches also encroached on part of the broken forest land with high ecological value in the southwestern and northern areas. Moreover, there were $164.53 \mathrm{~km}^{2}$ of construction land patches with mid-level ESP using UGB II. In contrast, the encroachment of UGB I by construction land on low-level and mid-level ESP areas with high ecological value was less than that of UGB II in the study area. Accordingly, the UGB of the NCMA with dynamic adjustment was more optimized than that without dynamic adjustment in the protection of ecological land.

\subsection{Qualitative Comparison of UGBs with Regional Planning Layout}

In recent decades, the UGB has been increasingly used as a planning tool by local governments to constrain urban development to a fixed area [35]. To verify the rationality of the delineated UGB, we compared the adjusted UGB of the NCMA in 2025 with the requirements proposed in the general plan (2006-2020) and master plan (2016-2035) of Nanchang. These two plans claim to follow the urban space development strategy of "westward advancement, eastward expansion, southward extension, and northern control", and strive to form an overall spatial development pattern of "taking Ganjiang River as the 
main axis, with one river and two banks; developing two cities respectively on the north and south banks, with dual cores supporting the river; achieving clustered and network development". According to the comparative results, the UGB delineated in this study was consistent with the development trend specified in the regional planning layout for the main part.

Specifically, the expansion of construction land was remarkable in the western part of the study area, which is basically in line with the general plan requirements of "constructing a multi-functional integrated modern new urban center in western Nanchang". Furthermore, it is necessary to strengthen the construction of regional urban infrastructure and land consolidation to improve land-use efficiency and meet the planning requirements in the future. In the eastern part of the study area, the expanded construction land area filled the gap between the high-tech zone and the central city. This situation is consistent with the development trend determined in the general plan of "making eastern Nanchang a comprehensive new area with a favorable ecological environment". The eastern part of Nanchang City adjacent to Poyang Lake is influenced by long-term sediment deposition. Therefore, it requires consideration of constructive land intensiveness and compactness while extending outward.

The construction land in the southern part of the study area continues to spread southward based on the existing construction land. This expansion trend is in accordance with the direction of "improving connotation development" specified by the general plan of Nanchang. During the continuous expansion of construction land toward the south, the occupation of cultivated land and the encroachment of ecological land should be prevented in the future. The expansion of construction land in the northern part of the study area is mainly distributed within the scope of the Sanghai Economic Zone in Xinjian District and the Technological Development Zone in the Nanchang District. This distribution pattern conforms to the concept of a "new urban area in suburban clusters" that the general plan has focused on. In the future, attention should be paid to building an ecological environment protection zone with excellent ecology, on the basis of satisfying regional development. This protection zone will guarantee the construction of leisure backyard gardens in the suburbs as proposed in the master plan of Nanchang.

\subsection{Methodological Advantages}

The current exploration of UGB delineation methodology is more "a hundred schools of thought contend", and there is no canonical delineation method. From the ecological protection and urban growth perspectives, this study designed and constructed a UGB delineation framework that coupled ESP establishment and CLE simulation. The establishment of ESP and multi-scenario simulation of CLE are relatively complex processes. First, the ESP is established based on the $i M C R$ model to determine the level of regional ecological security. Then, multi-scenario simulation of CLE is realized based on the CA-Markov model, and the optimal expansion simulation scenario is selected based on landscape pattern indexes. Finally, the UGB is obtained by dynamic adjustment with the results of ESP establishment and CLE simulation, which could satisfy the dual needs of ecological protection and urban growth.

Unlike previous studies [52,57,62], the present study established ESP based on the identification of both global and local ecological sources at the macro and micro levels. The global ecological sources were identified by direct picking, while the local ecological sources were identified in terms of ecological importance, landscape connectivity, and ecological demand. The ecological sources identified were coincidental with the actual state of the study area, which can be used to accurately protect regional ecological security. Moreover, this study considered the constraints of ecological sources during the course of expansion with regard to expansion resistance and obstacles. This consideration is crucial to constructing a scientific and reasonable ESP.

In delineating the UGB, this study included ESP establishment and CLE simulation as two independent processes. Through the coupling of the two processes, the dynamic 
adjustment of UGB delineation was realized, which is conducive to the coordination of urban development and ecological protection. In addition, a UGB in the traditional sense is the concept of a "line" [29,35]. In the present study, the UGB is the concept of a "facet" [41], which represents the spatial layout range of urban land in future development, and has an explicit spatial orientation.

\subsection{Research Limitations and Future Directions}

This study developed an operational and transdisciplinary framework for UGB delineation. The proposed framework can be applied in similar urbanized cities to facilitate regional sustainable development. However, it has some limitations. First, the resistance surface during the expansion of ecological sources is the key to ESP establishment, which still needs further exploration and improvement. Second, the influence of land price, planning, and other policy factors in different areas were not considered in the simulation of CLE based on the CA-Markov model in this study. Moreover, taking accuracy into consideration, this study only simulated the land use in 2025 without considering the medium- and long-term development of the NCMA. Furthermore, due to the lack of relevant planning documents, this study only verified the UGB delineation results with respect to the "layout control".

Therefore, it is necessary to further study methods for selecting the resistance surface in the expansion of ecological sources during the later stage and construct a comprehensive and perfect resistance surface index system. Furthermore, the comprehensiveness of driving factors and the stage of data should be integrated into follow-up studies for a synchronized simulation in near-, medium-, and long-term periods to obtain future development trends and forms of cities. Moreover, it is expected that the rationality of the delineation method can be verified based on the perspective of "amount control" in the future, combined with more planning materials.

\section{Conclusions}

A UGB delineation framework that coupled ESP establishment and CLE simulation was developed and applied to the NCMA. The results showed that the core ESP accounted for nearly half of the total study area in 2018, and constituted an indisputable bottom line for regional development to warrant ecological security. Multi-scenario simulation based on landscape pattern indexes indicated that the natural development scenario was optimal for regional socio-economic and ecological development. In the optimal scenario, the UGB of the NCMA in 2025 was obtained at $687.87 \mathrm{~km}^{2}$. The rationality and scientificity of the proposed framework were verified by comparative analysis of the UGB delineation results in terms of the scale and layout. The proposed framework involves the identification of both global and local ecological sources. It considers regional ecological security comprehensively from the ecological protection perspective and meets the requirements of future development from the urban growth perspective. The framework provides a useful tool for the UGB delineation of rapidly urbanized cities to achieve a win-win outcome of ecological security and urban development.

Supplementary Materials: The following supporting information can be downloaded at: https: / / www.mdpi.com/article/10.3390/land11030359/s1, Table S1: List of main data used in this study; Table S2: Ranges and descriptions of landscape pattern indexes used for optimal scenario selection; Figure S1: Selected indexes for the evaluation of local ecological sources; Figure S2. Spatial distributions of factors driving construction land expansion in the study area.

Author Contributions: Conceptualization, D.Y.; methodology, D.Y. and X.G.; software, D.Y. and Y.H.; validation, D.Y., X.G. and Y.H.; data curation, D.Y.; writing-original draft preparation, D.Y.; writing-review and editing, X.G. and J.G.; visualization, Y.H.; funding acquisition, J.G., M.O. and $X . Z$. All authors have read and agreed to the published version of the manuscript.

Funding: This research was funded by the National Natural Science Foundations of China (71774086, 72174089) and the National Key R and D Program of China (No. 2017YFD0301603). 


\section{Institutional Review Board Statement: Not applicable.}

Informed Consent Statement: Not applicable.

Data Availability Statement: Not applicable.

Conflicts of Interest: The authors declare no conflict of interest.

\section{References}

1. Seto, K.C.; Sánchez-Rodríguez, R.; Fragkias, M. The new geography of contemporary urbanization and the environment. Annu. Rev. Environ. Resour. 2010, 35, 167-194. [CrossRef]

2. Angel, S.; Parent, J.; Civco, D.L.; Blei, A.; Potere, D. The dimensions of global urban expansion: Estimates and projections for all countries, 2000-2050. Prog. Plan. 2011, 75, 53-107. [CrossRef]

3. Seto, K.C.; Güneralp, B.; Hutyra, L.R. Global forecasts of urban expansion to 2030 and direct impacts on biodiversity and carbon pools. Proc. Natl. Acad. Sci. USA 2012, 109, 16083-16088. [CrossRef]

4. Calafati, A. Urban Sprawl Italian Style. Ital. J. Reg. Sci. 2011, 7, 99-108. [CrossRef]

5. Morollón, F.R.; Marroquin, V.M.G.; Rivero, J.L.P. Urban sprawl in Spain: Differences among cities and causes. Eur. Plan. Stud. 2016, 24, 207-226. [CrossRef]

6. Couch, C.; Karecha, J. Controlling urban sprawl: Some experiences from Liverpool. Cities 2006, 23, 353-363. [CrossRef]

7. Pirotte, A.; Madre, J. Determinants of Urban Sprawl in France: An Analysis Using a Hierarchical Bayes Approach on Panel Data. Urban. Stud. 2011, 48, 2865-2886. [CrossRef]

8. Stokel-Walker, C. Alpha City. In How London Was Captured by the Super-Rich; Verso: London, UK, 2020.

9. Stein, S. Capital City. In Gentrification and the Real Estate State; Verso: London, UK; New York, NY, USA, 2019.

10. Wang, L.; Pijanowski, B.; Yang, W.; Zhai, R.; Omrani, H.; Li, K. Predicting multiple land use transitions under rapid urbanization and implications for land management and urban planning: The case of Zhanggong District in central China. Habitat Int. 2018, 82, 48-61. [CrossRef]

11. Bathrellos, G.D.; Skilodimou, H.D.; Chousianitis, K.; Youssef, A.M.; Pradhan, B. Suitability estimation for urban development using multi-hazard assessment map. Sci. Total Environ. 2017, 575, 119-134. [CrossRef]

12. Bren, D.; Amour, C.; Reitsma, F.; Baiocchi, G.; Barthel, S.; Güneralp, B.; Erb, K.; Haberl, H.; Creutzig, F.; Seto, K.C. Future urban land expansion and implications for global croplands. Proc. Natl. Acad. Sci. USA 2017, 114, 8939-8944. [CrossRef]

13. Vaz, E.; Nijkamp, P. Gravitational forces in the spatial impacts of urban sprawl: An investigation of the region of Veneto, Italy. Habitat Int. 2015, 45, 99-105. [CrossRef]

14. Skog, K.L.; Steinnes, M. How do centrality, population growth and urban sprawl impact farmland conversion in Norway? Land Use Policy 2016, 59, 185-196. [CrossRef]

15. Huang, Z.; Du, X.; Castillo, C.S.Z. How does urbanization affect farmland protection? Evidence from China. Resour. Conserv. Recycl. 2019, 145, 139-147. [CrossRef]

16. He, J.; Liu, Y.; Yu, Y.; Tang, W.; Xiang, W.; Liu, D. A counterfactual scenario simulation approach for assessing the impact of farmland preservation policies on urban sprawl and food security in a major grain-producing area of China. Appl. Geogr. 2013, 37, 127-138. [CrossRef]

17. Dupras, J.; Marull, J.; Parcerisas, L.; Coll, F.; Tello, E. The impacts of urban sprawl on ecological connectivity in the Montreal Metropolitan Region. Environ. Sci. Policy 2016, 58, 61-73. [CrossRef]

18. Vimal, R.; Geniaux, G.; Pluvinet, P.; Napoleone, C.; Lepart, J. Detecting threatened biodiversity by urbanization at regional and local scales using an urban sprawl simulation approach: Application on the French Mediterranean region. Landsc. Urban Plan. 2012, 104, 343-355. [CrossRef]

19. Shoemaker, D.A.; BenDor, T.K.; Meentemeyer, R.K. Anticipating trade-offs between urban patterns and ecosystem service production: Scenario analyses of sprawl alternatives for a rapidly urbanizing region. Comput. Environ. Urban Syst. 2019, 74, 114-125. [CrossRef]

20. Zhou, Y.; Huang, X.; Chen, Y.; Zhong, T.; Xu, G.; He, J.; Xu, Y.; Meng, H. The effect of land use planning (2006-2020) on construction land growth in China. Cities 2017, 68, 37-47. [CrossRef]

21. Halleux, J.M.; Marcinczak, S.; Krabben, E. The adaptive efficiency of land use planning measured by the control of urban sprawl. The cases of the Netherlands, Belgium and Poland. Land Use Policy 2012, 29, 887-898. [CrossRef]

22. Gennaio, M.P.; Hersperger, A.M.; Bürgi, M. Containing urban sprawl—Evaluating effectiveness of urban growth boundaries set by the Swiss Land Use Plan. Land Use Policy 2009, 26, 224-232. [CrossRef]

23. Sharaf, S.A.; Serra, P.; Saurí, D. A district and sector land-use and landscape analysis of urban sprawl in Al Ain municipality (United Arab Emirates): Just a quick conversion from sand to a built-up environment? Appl. Geogr. 2018, 95, 88-100. [CrossRef]

24. Wang, L.G.; Han, H.; Lai, S.K. Do plans contain urban sprawl? A comparison of Beijing and Taipei. Habitat. Int. 2014, 42, 121-130. [CrossRef]

25. Bidandi, F.; Williams, J.J. Understanding urban land, politics, and planning: A critical appraisal of Kampala's urban sprawl. Cities 2020, 106, 102858. [CrossRef] 
26. Lei, Y.; Flacke, J.; Schwarz, N. Does Urban planning affect urban growth pattern? A case study of Shenzhen, China. Land Use Policy 2021, 101, 105100. [CrossRef]

27. Nelson, A.C.; Moore, T. Assessing urban growth management: The case of Portland, Oregon, the USA's largest urban growth boundary. Land Use Policy 1993, 10, 293-302. [CrossRef]

28. Long, Y.; Han, H.; Tu, Y.; Shu, X. Evaluating the effectiveness of urban growth boundaries using human mobility and activity records. Cities 2015, 46, 76-84. [CrossRef]

29. Ding, C.; Knaap, G.J.; Hopkins, L.D. Managing Urban Growth with Urban Growth Boundaries: A Theoretical Analysis. J. Urban Econ. 1999, 46, 53-68. [CrossRef]

30. Pendall, R. Holding the Line: Urban Containment in the United States; The Brookings Institution Center on Urban and Metropolitan Policy: Washington, DC, USA, 2002.

31. Gallent, N.; Bianconi, M.; Andersson, J. Planning on the edge: England's rural-urban fringe and the spatial-planning agenda. Environ. Plan. B Plan. Des. 2006, 33, 457-476. [CrossRef]

32. Staley, S.; Edgens, J.G.; Mildner, C.S.G. A Line in the Land: Urban Growth Boundaries, Smart Growth, and Housing Affordability; Reason Public Policy Institute: Los Angeles, CA, USA, 1999.

33. Moffett, K.B.; Makido, Y.; Shandas, V. Urban-Rural Surface Temperature Deviation and Intra-Urban Variations Contained by an Urban Growth Boundary. Remote Sens. 2019, 11, 2683. [CrossRef]

34. Chakraborti, S.; Das, D.N.; Mondal, B.; Shafizadeh-Moghadam, H.; Feng, Y. A neural network and landscape metrics to propose a flexible urban growth boundary: A case study. Ecol. Indic. 2018, 93, 952-965. [CrossRef]

35. Tayyebi, A.; Pijanowski, B.C.; Tayyebi, A.H. An urban growth boundary model using neural networks, GIS and radial parameterization: An application to Tehran, Iran. Landsc. Urban Plan. 2011, 100, 35-44. [CrossRef]

36. Long, Y.; Han, H.; Lai, S.; Mao, Q. Urban growth boundaries of the Beijing Metropolitan Area: Comparison of simulation and artwork. Cities 2013, 31, 337-348. [CrossRef]

37. Ma, S.; Li, X.; Cai, Y. Delimiting the urban growth boundaries with a modified ant colony optimization model. Comput. Environ. Urban Syst. 2017, 62, 146-155. [CrossRef]

38. Liu, J.; Zhang, G.; Zhuang, Z.; Cheng, Q.; Gao, Y.; Chen, T.; Huang, Q.; Xu, L.; Chen, D. A new perspective for urban development boundary delineation based on SLEUTH-InVEST model. Habitat Int. 2017, 70, 13-23. [CrossRef]

39. Ye, Y.; Su, Y.; Zhang, H.; Liu, K.; Wu, Q. Construction of an ecological resistance surface model and its application in urban expansion simulations. J. Geogr. Sci. 2015, 25, 211-224. [CrossRef]

40. Deng, Y.; Liu, Y.; Fu, B. Urban growth simulation guided by ecological constraints in Beijing city: Methods and implications for spatial planning. J. Environ. Manag. 2019, 243, 402-410. [CrossRef]

41. Yang, X.; Bai, Y.; Che, L.; Qiao, F.; Xie, L. Incorporating ecological constraints into urban growth boundaries: A case study of ecologically fragile areas in the Upper Yellow River. Ecol. Indic. 2021, 124, 107436. [CrossRef]

42. Liang, X.; Liu, X.; Li, X.; Chen, Y.; Tian, H.; Yao, Y. Delineating multi-scenario urban growth boundaries with a CA-based FLUS model and morphological method. Landsc. Urban Plan. 2018, 177, 47-63. [CrossRef]

43. Jiang, P.; Cheng, Q.; Gong, Y.; Wang, L.; Zhang, Y.; Cheng, L.; Li, M.; Lu, J.; Duan, Y.; Huang, Q.; et al. Using Urban Development Boundaries to Constrain Uncontrolled Urban Sprawl in China. Ann. Am. Assoc. Geogr. 2016, 106, 1321-1343. [CrossRef]

44. He, Q.; Tan, R.; Gao, Y.; Zhang, M.; Xie, P.; Liu, Y. Modeling urban growth boundary based on the evaluation of the extension potential: A case study of Wuhan city in China. Habitat Int. 2018, 72, 57-65. [CrossRef]

45. Huang, D.; Huang, J.; Liu, T. Delimiting urban growth boundaries using the CLUE-S model with village administrative boundaries. Land Use Policy 2019, 82, 422-435. [CrossRef]

46. Li, Y.; Ma, Q.; Song, Y.; Han, H. Bringing conservation priorities into urban growth simulation: An integrated model and applied case study of Hangzhou, China. Resour. Conserv. Recycl. 2019, 140, 324-337. [CrossRef]

47. Zhang, D.; Liu, X.; Lin, Z.; Zhang, X.; Zhang, H. The delineation of urban growth boundaries in complex ecological environment areas by using cellular automata and a dual-environmental evaluation. J. Clean. Prod. 2020, 256, 120361. [CrossRef]

48. Wang, W.; Jiao, L.; Zhang, W.; Jia, Q.; Su, F.; Xu, G.; Ma, S. Delineating urban growth boundaries under multi-objective and constraints. Sustain. Cities Soc. 2020, 61, 102279. [CrossRef]

49. Wang, W.; Jiao, L.; Dong, T.; Xu, Z.; Xu, G. Simulating urban dynamics by coupling top-down and bottom-up strategies. Int. J. Geogr. Inf. Sci. 2019, 33, 2259-2283. [CrossRef]

50. Li, Q.; Wang, L.; Gul, H.N.; Li, D. Simulation and optimization of land use pattern to embed ecological suitability in an oasis region: A case study of Ganzhou district, Gansu province, China. J. Environ. Manag. 2021, 287, 112321. [CrossRef] [PubMed]

51. Xiang, Y.; Meng, J. Research into ecological suitability zoning and expansion patterns in agricultural oases based on the landscape process: A case study in the middle reaches of the Heihe River. Environ. Earth Sci. 2016, 75, 1355. [CrossRef]

52. Peng, J.; Yang, Y.; Liu, Y.; Hu, Y.; Du, Y.; Meersmans, J.; Qiu, S. Linking ecosystem services and circuit theory to identify ecological security patterns. Sci. Total Environ. 2018, 644, 781-790. [CrossRef]

53. Kang, J.; Zhang, X.; Zhu, X.; Zhang, B. Ecological security pattern: A new idea for balancing regional development and ecological protection. A case study of the Jiaodong Peninsula, China. Glob. Ecol. Conserv. 2021, 26, e01472. [CrossRef]

54. Zhou, L.; Dang, X.; Sun, Q.; Wang, S. Multi-scenario simulation of urban land change in Shanghai by random forest and CA-Markov model. Sustain. Cities Soc. 2020, 55, 102045. [CrossRef] 
55. Jafari, M.; Majedi, H.; Monavari, S.M.; Alesheikh, A.A.; Zarkesh, M.K. Dynamic simulation of urban expansion through a CA-Markov model Case study: Hyrcanian region, Gilan, Iran. Eur. J. Remote Sens. 2016, 49, 513-529. [CrossRef]

56. Wang, C.; Yu, C.; Chen, T.; Feng, Z.; Hu, Y.; Wu, K. Can the establishment of ecological security patterns improve ecological protection? An example of Nanchang, China. Sci. Total Environ. 2020, 740, 140051. [CrossRef] [PubMed]

57. Fu, Y.; Shi, X.; He, J.; Yuan, Y.; Qu, L. Identification and optimization strategy of county ecological security pattern: A case study in the Loess Plateau, China. Ecol. Indic. 2020, 112, 106030. [CrossRef]

58. Yu, K. Security patterns and surface model in landscape ecological planning. Landsc. Urban Plan. 1996, 36, 1-17. [CrossRef]

59. Li, S.; Xiao, W.; Zhao, Y.; Lv, X. Incorporating ecological risk index in the multi-process MCRE model to optimize the ecological security pattern in a semi-arid area with intensive coal mining: A case study in northern China. J. Clean. Prod. 2020, 247, 119143. [CrossRef]

60. Liu, G.; Liang, Y.; Cheng, Y.; Wang, H.; Lu, Y. Security Patterns and Resistance Surface Model in Urban Development: Case Study of Sanshui, China. J. Urban. Plan. Dev. 2017, 143, 05017011. [CrossRef]

61. Saaty, T.L. How to Make a Decision: The Analytic Hierarchy Process. Eur. J. Oper. Res. 1994, 48, 9-26. [CrossRef]

62. Wang, Y.; Pan, J. Building ecological security patterns based on ecosystem services value reconstruction in an arid inland basin: A case study in Ganzhou District, NW China. J. Clean. Prod. 2019, 241, 118337. [CrossRef]

63. Chen, J.; Chang, K.; Karacsonyi, D.; Zhang, X. Comparing urban land expansion and its driving factors in Shenzhen and Dongguan, China. Habitat Int. 2014, 43, 61-71. [CrossRef]

64. Yang, X.; Zheng, X.; Chen, R. A land use change model: Integrating landscape pattern indexes and Markov-CA. Ecol. Model. 2014, 283, 1-7. [CrossRef]

65. Zhou, Z.X.; Li, J. The correlation analysis on the landscape pattern index and hydrological processes in the Yanhe watershed, China. J. Hydrol. 2015, 524, 417-426. [CrossRef]

66. Ariken, M.; Zhang, F.; Liu, K.; Fang, C.; Kung, H. Coupling coordination analysis of urbanization and eco-environment in Yanqi Basin based on multi-source remote sensing data. Ecol. Indic. 2020, 114, 106331. [CrossRef]

67. Sharp, R.; Tallis, H.T.; Ricketts, T.; Guerry, A.D.; Wood, S.A.; Chaplin-Kramer, R.; Nelson, E.; Ennaanay, D.; Wolny, S.; Olwero, N.; et al. InVEST3.3.3 User's Guide; The Natural Capital Project; Stanford University: Stanford, CA, USA; University of Min-Nesota: Minneapolis, MN, USA; The Nature Conservancy: Arlington, VA, USA; World Wildlife Fund: San Francisco, CA, USA, 2016.

68. Han, Y.; Guo, X.; Jiang, Y.; Xu, Z.; Li, Z. Environmental factors influencing spatial variability of soil total phosphorus content in a small watershed in Poyang Lake Plain under different levels of soil erosion. Catena 2020, 187, 104357. [CrossRef]

69. Chen, Y.; Li, B.; Li, Z.; Li, W. Water resource formation and conversion and water security in arid region of Northwest China. J. Geogr. Sci. 2016, 26, 939-952. [CrossRef]

70. Saura, S.; Torné, J. Conefor Sensinode 2.2: A software package for quantifying the importance of habitat patches for landscape connectivity. Environ. Model. Softw. 2009, 24, 135-139. [CrossRef]

71. Wu, J.; Ma, L.; Li, W.; Peng, J.; Liu, H. Dynamics of Urban Density in China: Estimations Based on DMSP/OLS Nighttime Light Data. IEEE J-STARS 2017, 7, 4266-4275. [CrossRef]

72. Shi, Y.; Li, J.; Xie, M. Evaluation of the ecological sensitivity and security of tidal flats in Shanghai. Ecol. Indic. 2018, 85, 729-741. [CrossRef]

73. Song, H.; Lu, B.; Ye, C.; Li, J.; Zhu, Z.; Zheng, L. Fraud vulnerability quantitative assessment of Wuchang rice industrial chain in China based on AHP-EWM and ANN methods. Food Res. Int. 2021, 140, 109805. [CrossRef]

74. Barros, K.D.O.; Antonio, A.S.R.C.; Marcatti, G.E.; Lorenzon, A.S.; Lemos, M.D.C.N.; Domingues, G.F.; De Carvalho, J.R.; Dos Santos, A.R. Markov chains and cellular automata to predict environments subject to desertification. J. Environ. Manag. 2018, 225, 160-167. [CrossRef]

75. Cohen, J. A Coefficient of Agreement for Nominal Scales. Educ. Psychol. Meas. 1960, 20, 37-46. [CrossRef]

76. Koch, L.G.G. The measurement of observer agreement for categorical data. Biometrics 1977, 33, 159-174. [CrossRef] 